\title{
Size and Persistence of Nitrous Oxide Hot-Spots in Grazed and Ungrazed Grassland
}

\author{
Paul R. Hargreaves ${ }^{1}$, Robert M. Rees ${ }^{2}$, Graham W. Horgan ${ }^{3} \&$ Bruce C. Ball $^{4}$ \\ ${ }^{1}$ Dairy Research Centre, SRUC, West Mains Road, Edinburgh, EH9 3JG, UK \\ ${ }^{2}$ Carbon Management Centre, SRUC, West Mains Road, Edinburgh, EH9 3JK, UK \\ ${ }^{3}$ Biomathematics and Statistics Scotland, Aberdeen, AB21 9SB, UK \\ ${ }^{4}$ Crop and Soil Systems Research Group, SRUC, West Mains Road, Edinburgh, EH9 3JK, UK \\ Correspondence: Paul R. Hargreaves, Dairy Research Centre, SRUC, West Mains Road, Edinburgh, EH9 3JG, \\ UK. Tel: 44-013-8726-3961 Email: Paul.Hargreaves@sruc.ac.uk
}

\author{
Received: June 11, 2015 Accepted: July 28, 2015 Online Published: September 22, 2015 \\ doi:10.5539/enrr.v5n4p1 URL: http://dx.doi.org/10.5539/enrr.v5n4p1
}

\begin{abstract}
Nitrous oxide $\left(\mathrm{N}_{2} \mathrm{O}\right)$ emissions from agriculture contributed an estimated $60 \%$ of the global total in 2005 . In the UK, grassland soils account for $30 \%$ of total emissions, $22 \%$ of which are estimated to come from urine and dung patches. These patches are possible sources of 'hot-spots' (area $c a .1 \mathrm{~m}^{2}$ ) of $\mathrm{N}_{2} \mathrm{O}$ fluxes. Spatial and temporal heterogeneity of $\mathrm{N}_{2} \mathrm{O}$ hot-spot fluxes were investigated in three grassland fields (grazed with dairy cows (DG), grazed with young stock (YG) or cut for silage (SC)) using gas sampling chambers surrounding historic hot-spots to establish their size. Fluxes from old dung and urine patches were measured, as well as freshly applied dung and urine to simulate the creation of hot-spots. Potential chemical and physical drivers were also measured. Large spatial variability of $\mathrm{N}_{2} \mathrm{O}$ fluxes was seen in all three grassland fields. Mean $\mathrm{N}_{2} \mathrm{O}$ fluxes for the historic hot-spots in the grazed fields (DG and YG) were significantly greater than (SC). The mean $\mathrm{N}_{2} \mathrm{O}$ fluxes in DG and YG (117.9 and $243.5 \mathrm{ng} \mathrm{N} \mathrm{m}^{-2} \mathrm{~s}^{-1}$ ) were 15 to $30 \%$ greater than for SC. Soil temperature (15 $20{ }^{\circ} \mathrm{C}$ ) was the most significant driver of $\mathrm{N}_{2} \mathrm{O}$ production with a $1^{\circ} \mathrm{C}$ rise in soil temperature increasing emissions under DG and YG. $\mathrm{N}_{2} \mathrm{O}$ fluxes were enhanced by the fresh dung but not by urine. However, in the urine treatment, the nutrient input increased the microbial respiration response for the $\mathrm{CO}_{2}$ flux. Hot-spot $\mathrm{N}_{2} \mathrm{O}$ emissions from old urine and dung patches were persistent several months after application.
\end{abstract}

Key words: dung, grassland, grazed, hot-spots, nitrous oxide, urine

\section{Introduction}

Nitrous oxide $\left(\mathrm{N}_{2} \mathrm{O}\right)$ has been recognised as a major contributor to anthropogenic warming (Houghton \& Ding, 2001), with a global warming potential estimated at 298 times that of carbon dioxide $\left(\mathrm{CO}_{2}\right)(\mathrm{IPCC}, 2007)$. $\mathrm{N}_{2} \mathrm{O}$ is also broken down in the stratosphere in reactions that deplete stratospheric ozone (Crutzen, 1981; Ravishankara, Daniel, Portman, 2009). Agricultural sources are mainly from soil and contributed $\sim 60 \%$ to the global total in 2005 (Smith et al., 2007; Reay et al., 2012), with 30\% of the UK agricultural emissions from grassland (Fowler, Hargreaves, Skiba, \& Bower, 1999; Skiba et al., 2012; Sozanska, Skiba, \& Metcalfe, 2002). Production and emissions of $\mathrm{N}_{2} \mathrm{O}$ are increased by the addition of nitrogen $(\mathrm{N})$ in the form of mineral or organic fertilisers and residues. Under grazing, concentrations of $\mathrm{N}$ from cattle urine and dung deposits are high and both increase emissions (van der Weerden, Lu, de Klein, Hoogendoorn, Littlejohn, Rys, 2011); the dung also contains a readily available carbon source. Within the UK, Yamulki, Jarvis, and Owen (1998) estimated that 22\% of emissions of $\mathrm{N}_{2} \mathrm{O}$ from grassland originated from urine and dung patches.

The main $\mathrm{N}$ component of urine is urea $\left(\mathrm{NH}_{2} \mathrm{CONH}_{2}\right)$ making up $70 \%$ of its $\mathrm{N}$ composition (Oenema, Velthof, Yamulki, \& Jarvis, 1997). Urea from urine deposited on grassland soil is transformed to ammonium $\left(\mathrm{NH}_{4}^{+}\right)$by hydrolysis within 24-48 hours through several microbial pathways that provide important sources of $\mathrm{N}_{2} \mathrm{O}$ emissions (Clough, Ledgard, Sprosen, \& Kear, 1998; Monaghan \& Barraclough, 1993; Wrage, Velthof, van Beusichem, \& Oenema, 2001). An estimation of $\mathrm{N}_{2} \mathrm{O}$ losses from urine deposition to grassland by Williams, Ineson, Cowards (1999) indicated that approximately $8 \%$ of the annual urine-N was lost within the first 24 hours. Soil denitrification from urine additions is considered to be dependent on the amount of $\mathrm{NH}_{4}{ }^{+}$produced $(\mathrm{Carter}$, 
Klumpp, \& Le Roux, 2006). Denitrification can also be stimulated by carbon compounds, as C is mobilised from roots scorched by the urine (Monaghan \& Barraclough, 1993; Ambus, Petersen, \& Soussana, 2007). A small number of studies of the variation of $\mathrm{N}_{2} \mathrm{O}$ emissions as a result of dung and urine patches on grassland indicate that soil type (as a combination of physical or chemical properties) could also influence emissions (Ball, Horgan, Clayton, \& Parker, 1997; Velthof, Jarvis, Stein, Allen, \& Oenema, 1996). However, most investigations have focused on the affect of a limited number of driving variables.

Van Groenigen, Velthof, van der Bolt, Vos, and Kuikman. (2005a) considered soil compaction and seasonal emissions, both in the field and in pot experiments, from urine and dung patches and found that water filled pore space (WFPS) enhanced $\mathrm{N}_{2} \mathrm{O}$ emissions in the short term and that soil compaction would increase emissions over a season (van Groenigen, Kuikman, de Groot, Velthof, 2005b). These factors of compaction and/or urine and dung patches gave 'hot-spots' of $\mathrm{N}_{2} \mathrm{O}$ emissions of $0.5-2 \mathrm{~m}$ in diameter.

Increased soil electrical conductivity from the accumulation of soluble salts to the soil, as occurs under urine patches, has been investigated as a proxy for $\mathrm{N}_{2} \mathrm{O}$ emissions. Adviento-Borbe, Doran, Drijber, Dobermann (2006) found that emissions of $\mathrm{N}_{2} \mathrm{O}$ increased with soil salt concentrations when WFPS was $90 \%$. Soil surface $\mathrm{pH}$ has been shown to be less important. Clough and Kelliher (2005) found, after the addition of urine, an initial rise in soil $\mathrm{pH}$ but there was no significant difference in $\mathrm{N}_{2} \mathrm{O}$ flux or soil $\mathrm{pH}$ compared to the control eleven days after application. In contrast, Orwin et al. (2010) found that urine maintained the soil surface pH above 7 for 29 days after application and thereafter the soil $\mathrm{pH}$ decreased below the control. Even though increased soil temperature should result in an increase in soil microbial activity, Yamulki et al. (1998) observed a correlation between $\mathrm{N}_{2} \mathrm{O}$ emission and soil temperature only at $10 \mathrm{~cm}$ depth during the autumn (mid-September).

The stimulation of $\mathrm{N}_{2} \mathrm{O}$ flux relative to $\mathrm{CO}_{2}$ flux has not been a common focus in other work associated with grassland. Scott, Ball, Crichton, and Aitken (2000) considered the effect of sewage sludge application to grassland on $\mathrm{N}_{2} \mathrm{O}$ and $\mathrm{CO}_{2}$ emissions and found short term temporal variability related to rainfall events and diurnal temperature change. Owing to the marked temporal variability of both gases, we considered it useful to measure these fluxes during this work. Our investigations had three aims. The first was to measure spatial heterogeneity of $\mathrm{N}_{2} \mathrm{O}$ and $\mathrm{CO}_{2}$ fluxes from gas sampling chambers in three grassland fields (one grazed by dairy cattle (DG), one grazed by young stock ( $\mathrm{YG}$ ) and one cut for silage (SC)) around locations of regular, elevated $\mathrm{N}_{2} \mathrm{O}$ fluxes, to establish the size and extent of any historic hot-spot and the soil properties that may account for the fluxes. The second was to identify possible recent sources of hot-spots of $\mathrm{N}_{2} \mathrm{O}$ fluxes from measurements taken under old dung or urine patches, along with measured soil physical and chemical properties. The third was to create fresh hot-spots by applying dung and urine to grassland to establish any immediate change of $\mathrm{N}_{2} \mathrm{O}$ and $\mathrm{CO}_{2}$ flux.

\section{Materials and Methods}

\subsection{Site Description}

The measurements took place in three grass fields on the Crichton Royal Farm situated on the south side of Dumfries, south west Scotland $\left(55^{\circ} 02.5^{\prime} \mathrm{N}, 3^{\circ} 35.3^{\circ} \mathrm{W}\right)$. One was grazed by dairy cattle (DG), high intensity management, another was grazed by young stock $(\mathrm{YG})$, medium intensity of grazing management and the third was cut for silage (SC). The three fields all received different amounts of $\mathrm{N}$ during the six months prior to the study (Table 1). All were on freely draining sandy loam brown forest soils of the Crichton series (Eutric Cambisol; FAO classification). In each field there was already a group of 6 closed static chambers, $40 \mathrm{~cm}$ diameter, in place for the regular measurement of $\mathrm{N}_{2} \mathrm{O}$ fluxes. Average annual totals of fluxes from these sites were very high, $21.2 \mathrm{~kg} \mathrm{~N}_{2} \mathrm{O}-\mathrm{N} \mathrm{ha}^{-1} \mathrm{yr}^{-1}$, with the main driving variable being total $\mathrm{N}$ applied (Rees et al., 2013). During our investigation all the gas flux measurements and soil sampling were taken over the course of two days in June 2007.

Table 1. Fertiliser application $\left(\mathrm{kg} \mathrm{ha}^{-1}\right)$ to the three fields (Dairy Grazed (DG), grazed by Young Stock (YG) and Silage Cut (SC)) in the previous six months and the rainfall monthly totals (mm)

\begin{tabular}{llccccccc}
\hline & & January & February & March & April & May & (20-22 June) & Total \\
\hline N application (kg) & Dairy grazing (DG) & 50 & 40 & 80 & 35 & 35 & & 240 \\
& Young stock grazing (YG) & & & 50 & 50 & 35 & 35 & 170 \\
& Silage cut (SC) & & & 41 & 70 & 50 & 35 & 196 \\
Rainfall monthly total (mm) & & 129.9 & 86.7 & 95.2 & 21.6 & 64.9 & 72.3 & 470.6 \\
\hline
\end{tabular}




\subsection{Experimental Design}

\subsubsection{Spatial Variation around a Historic Hot-Spot Chamber}

In the first experiment, two of six regularly-assessed static gas sampling chambers (labeled ' $a$ ' and ' $b$ ') that gave consistently the highest $\mathrm{N}_{2} \mathrm{O}$ fluxes (taken to be on 'hot spots') in each field were surrounded with 2 concentric rings of 5 chambers at a radius of $1 \mathrm{~m}$ and $2 \mathrm{~m}$ (Figure 1). This configuration was chosen in an attempt to distinguish whether hot-spots of $\mathrm{N}_{2} \mathrm{O}$ emission were more associated with historic $\mathrm{N}$ deposition from dung and urine residues than with hot spots due to variations in topography that can cover areas up to several $\mathrm{m}^{2}$ (Ball et al., 1997). The configuration would also help to establish the size and location of any hot-spot. The pattern of the chamber placement was the same around each original hot-spot chamber in all three fields.

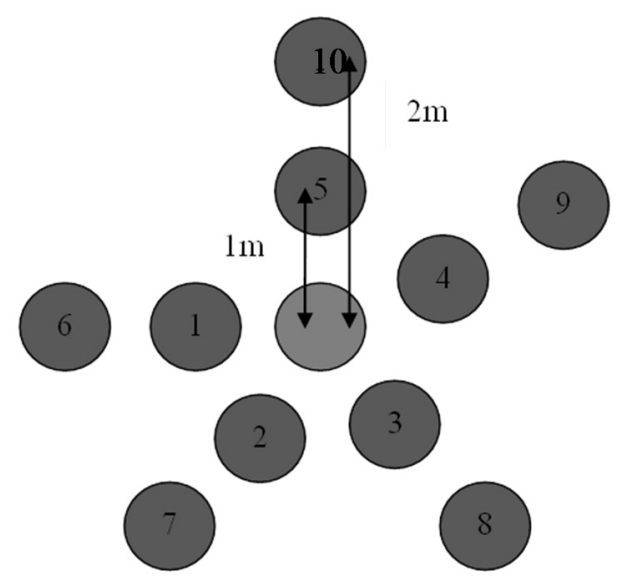

Figure 1. Gas sampling chambers pattern used around an historic hotspot chamber (unnumbered). $1 \mathrm{~m}$ and $2 \mathrm{~m}$ refer to the measured distances between chamber centres.

\subsubsection{Old Urine and Dung Patches}

In the field grazed by young stock (YG), four chambers were placed on localised areas of enhanced grass growth that had not been grazed but showed no indication of dung deposit and were assumed to indicate areas of old urine deposition, four chambers were placed on similar non-grazed grass that showed residual dung and four chambers were on areas that had average grazing.

\subsubsection{Fresh Urine and Dung Patches}

Three gas sampling chambers were embedded in the soil with freshly collected dung or synthetic urine applied. A further eight chambers had no additions and were placed around the field grazed by dairy cows, as controls. The rates of application of the dung and urine represented realistic deposition rates by cattle. The synthetic urine was made up according to Carter et al. (2006) as a solution of $0.7 \mathrm{~g} \mathrm{~N}^{-1}$, and was applied to the inside of the gas sampling chambers at a rate equivalent to $244 \mathrm{~kg} \mathrm{~N} \mathrm{ha}^{-1}$. The dung was applied at a rate equivalent to $200 \mathrm{~kg} \mathrm{~N}$ ha-1 (McGechan \& Topp, 2004).

All emission rates were measured using manually closed static chambers $0.2 \mathrm{~m}$ high polypropylene cylinders of $0.4 \mathrm{~m}$ diameter enclosing an area of $0.13 \mathrm{~m}^{2}$ embedded to a depth of $5 \mathrm{~cm}$ in the soil (Scott, Crichton, \& Ball, 1999). The chambers were left for 4 hours after installation before any flux measurements were taken. Prior to each sampling, several samples of ambient air were taken at the time of chamber closure and samples were taken from each chamber at the end of the closure period $(1 \mathrm{~h})$ in gas tight vials. Gas samples were analysed for $\mathrm{N}_{2} \mathrm{O}$ and $\mathrm{CO}_{2}$ in the laboratory using gas chromatography (Scott et al., 1999).

After the initial gas sampling, soil was collected from within each chamber to a depth of 0-20 cm and used for the determination of soil mineral $\mathrm{N}_{\left(\mathrm{NO}_{3}\right.}$ and $\mathrm{NH}_{4}{ }^{+}$), water content and $\mathrm{pH}$. Nitrate and $\mathrm{NH}_{4}{ }^{+}$were measured by continuous flow colorimetric analysis of $1 \mathrm{M} \mathrm{KCl}$ extracts prepared from field moist soil using a soil to extractant ratio of 1:5. Soil $\mathrm{pH}$ values were determined on suspensions of $10 \mathrm{~g}$ fresh soil in $25 \mathrm{ml}$ water. The soil moisture measurements were made with a Delta-T capacitance probe to a depth of $5 \mathrm{~cm}$, and soil temperature was measured at a depth of $10 \mathrm{~cm}$. 
The bulk density of the soil at $0-10 \mathrm{~cm}$ soil depth was measured by knocking metal rings of $7 \mathrm{~cm}$ diameter and $10 \mathrm{~cm}$ depth vertically into the ground and digging out the intact core. These soil cores were dried at $105^{\circ} \mathrm{C}$ for 24 hours and the bulk densities were used in conjunction with the soil moisture measurements to calculate the Water Filled Pore Space (WFPS).

\subsection{Statistical Methods}

Means were compared using two-sample t-tests. Pearson correlations were used to assess the association between variables. Data were assumed Normally distributed except for $\mathrm{N}_{2} \mathrm{O}$ fluxes, which were log-transformed before evaluation. All tests were performed at the $5 \%$ significance level.

\section{Results}

\subsection{Spatial Variation around a Historic Hotspot Chamber}

The measurements from the spatial variation sampling around the original hot-spot gas sampling chambers in the three fields are shown in Table 2 for dairy grazed (DG), Table 3 for silage cut (SC) and Table 4 for grazed by young stock (YG). Fluxes of $\mathrm{N}_{2} \mathrm{O}$ measured from the chambers surrounding the original hotspot chambers in each field were highly variable (Figure 2). The largest individual $\mathrm{N}_{2} \mathrm{O}$ fluxes of 2883.3 and $819.3 \mathrm{ng} \mathrm{N} \mathrm{m}^{-2} \mathrm{~s}^{-1}$, were from DG and were accompanied by corresponding high $\mathrm{CO}_{2}$ fluxes (Figure 3). The mean $\mathrm{N}_{2} \mathrm{O}$ fluxes for all the sampling chambers in the two grazed fields DG (243.5 $\left.\mathrm{ng} \mathrm{N} \mathrm{m}^{-2} \mathrm{~s}^{-1}, P<0.05\right)$ and YG (117.9 $\mathrm{ng} \mathrm{N} \mathrm{m}^{-2} \mathrm{~s}^{-1}$, $P<0.001)$ were significantly higher than the ungrazed field SC $\left(7.05 \mathrm{ng} \mathrm{N} \mathrm{m}^{-2} \mathrm{~s}^{-1}\right)$.

Table 2. Measured and mean values from the two sets of 10 gas sampling chambers ( $a$ and $b$ ) surrounding a chamber with high flux (original $\mathrm{a}+$ original $\mathrm{b}$ ) from the dairy-cattle grazed field (DG)

\begin{tabular}{|c|c|c|c|c|c|c|c|c|}
\hline Field & Chambers & $\begin{array}{l}\mathrm{N}_{2} \mathrm{O} \text { flux } \\
\mathrm{ng} \mathrm{N} \\
\mathrm{m}^{-2} \mathrm{~s}^{-1}\end{array}$ & $\begin{array}{l}\mathrm{CO}_{2} \text { flux } \\
\mathrm{ng} \mathrm{C} \\
\mathrm{m}^{-2} \mathrm{~s}^{-1}\end{array}$ & Temp ${ }^{\circ} \mathrm{C}$ & $\begin{array}{c}\text { WFPS } \\
\%\end{array}$ & $\begin{array}{l}\mathrm{NH}_{4}: \mathrm{N} \\
\text { (soil DM) } \mu \mathrm{g} \mathrm{g}^{-1}\end{array}$ & $\begin{array}{l}\mathrm{NO}_{3}: \mathrm{N} \\
\text { (soil DM) } \mu \mathrm{g} \mathrm{g}^{-1}\end{array}$ & $\begin{array}{l}\mathrm{pH} \\
\mathrm{H}_{2} \mathrm{O}\end{array}$ \\
\hline \multirow[t]{13}{*}{ Dairy Grazed (DG) } & Original a & 542.9 & 176.0 & 16.9 & 68.5 & 17.8 & 33.1 & $\mathrm{n} / \mathrm{a}$ \\
\hline & a.1 & 30.3 & 54.9 & 18.0 & 59.6 & 17.2 & 27.3 & $\mathrm{n} / \mathrm{a}$ \\
\hline & a. 2 & 2883.3 & 228.8 & 16.5 & 65.5 & 17.4 & 34.7 & $\mathrm{n} / \mathrm{a}$ \\
\hline & a. 3 & 22.9 & 75.7 & 17.5 & 77.9 & 18.8 & 37.5 & $\mathrm{n} / \mathrm{a}$ \\
\hline & a. 4 & 20.6 & 70.2 & 16.5 & 62.6 & 17.3 & 36.2 & $\mathrm{n} / \mathrm{a}$ \\
\hline & a. 5 & 8.3 & 15.9 & 18.5 & 68.7 & 17.8 & 36.2 & $\mathrm{n} / \mathrm{a}$ \\
\hline & a. 6 & 155.1 & 140.4 & 18.2 & 65.9 & 18.3 & 35.3 & $\mathrm{n} / \mathrm{a}$ \\
\hline & a.7 & 74.8 & 98.4 & 17.0 & 110.8 & 17.6 & 32.8 & $\mathrm{n} / \mathrm{a}$ \\
\hline & a. 8 & 4.3 & 21.7 & 16.7 & 72.0 & 18.0 & 34.4 & $\mathrm{n} / \mathrm{a}$ \\
\hline & a.9 & 106.2 & 60.8 & 17.7 & 49.5 & 18.3 & 34.6 & $\mathrm{n} / \mathrm{a}$ \\
\hline & a. 10 & 36.6 & 73.7 & 19.2 & 69.3 & 19.4 & 24.6 & $\mathrm{n} / \mathrm{a}$ \\
\hline & Mean & 353.2 & 92.4 & 17.5 & 70.0 & 18.0 & 33.3 & \\
\hline & $\mathrm{CV} \%$ & 241.6 & 70.4 & 5.1 & 21.9 & 3.7 & 11.8 & \\
\hline \multirow[t]{13}{*}{ Dairy Grazed (DG) } & Original $b$ & 109.2 & 89.4 & 17.8 & 63.0 & $\mathrm{n} / \mathrm{a}$ & $\mathrm{n} / \mathrm{a}$ & $\mathrm{n} / \mathrm{a}$ \\
\hline & b. 1 & 6.0 & 19.7 & 17.2 & 52.0 & 9.4 & 16.0 & 5.18 \\
\hline & b. 2 & 76.7 & 196.4 & 17.4 & 66.1 & 8.5 & 14.5 & 5.33 \\
\hline & b. 3 & 280.0 & 203.7 & 18.8 & 71.4 & 6.1 & 13.0 & 5.35 \\
\hline & b. 4 & 6.3 & 17.1 & 17.3 & 68.9 & 11.3 & 18.2 & 5.31 \\
\hline & b. 5 & 113.1 & 190.4 & 17.8 & 68.9 & 6.0 & 13.4 & 5.35 \\
\hline & b. 6 & 1.92 & 4.8 & 18.3 & 67.2 & 4.8 & 16.1 & 5.32 \\
\hline & b.7 & 10.0 & 18.9 & 17.6 & 62.4 & 11.9 & 14.9 & 5.14 \\
\hline & b. 8 & 819.3 & 102.7 & 18.0 & 65.5 & 8.8 & 19.0 & 5.41 \\
\hline & b. 9 & 54.8 & 115.3 & 18.3 & 65.9 & 8.9 & 15.2 & 5.37 \\
\hline & b. 10 & 6.9 & 18.1 & 19.4 & 46.8 & 6.3 & 29.2 & 5.56 \\
\hline & Mean & 134.9 & 88.8 & 18.0 & 63.5 & 8.2 & 16.9 & 5.33 \\
\hline & $\mathrm{CV} \%$ & 179.0 & 89.3 & 3.7 & 11.8 & 28.7 & 27.7 & 2.16 \\
\hline
\end{tabular}

n/a samples not analysed. 
Table 3. Measured and mean values from the two sets of 10 gas sampling chambers (a and b) surrounding a chamber with high flux (original a + original b) from the Silage Cut field (SC)

\begin{tabular}{|c|c|c|c|c|c|c|c|c|}
\hline Field & Chambers & $\begin{array}{l}\mathrm{N}_{2} \mathrm{O} \text { flux } \\
\mathrm{ng} \mathrm{N} \\
\mathrm{m}^{-2} \mathrm{~s}^{-1}\end{array}$ & $\begin{array}{l}\mathrm{CO}_{2} \text { flux } \\
\mathrm{ng} \mathrm{C} \\
\mathrm{m}^{-2} \mathrm{~s}^{-1}\end{array}$ & Temp ${ }^{\circ} \mathrm{C}$ & $\begin{array}{l}\text { WFPS } \\
\%\end{array}$ & $\mathrm{NH}_{4}: \mathrm{N}$ (soil DM) $\mu \mathrm{g} \mathrm{g}^{-1}$ & $\mathrm{NO}_{3}: \mathrm{N}$ (soil DM) $\mu \mathrm{g} \mathrm{g}^{-1}$ & $\begin{array}{l}\mathrm{pH} \\
\mathrm{H}_{2} \mathrm{O}\end{array}$ \\
\hline \multirow{13}{*}{$\begin{array}{l}\text { Silage Cut } \\
\text { (SC) }\end{array}$} & Original a & 5.2 & 71.3 & 15.4 & 92.0 & $\mathrm{n} / \mathrm{a}$ & $\mathrm{n} / \mathrm{a}$ & $\mathrm{n} / \mathrm{a}$ \\
\hline & a.1 & 0.3 & 31.9 & 16.3 & 94.5 & $\mathrm{n} / \mathrm{a}$ & $\mathrm{n} / \mathrm{a}$ & $\mathrm{n} / \mathrm{a}$ \\
\hline & a. 2 & 0.5 & 18.4 & 16.1 & 84.7 & $\mathrm{n} / \mathrm{a}$ & $\mathrm{n} / \mathrm{a}$ & $\mathrm{n} / \mathrm{a}$ \\
\hline & a. 3 & 5.5 & 109.7 & 16.5 & 95.7 & $\mathrm{n} / \mathrm{a}$ & $\mathrm{n} / \mathrm{a}$ & $\mathrm{n} / \mathrm{a}$ \\
\hline & a. 4 & 26.0 & 113.3 & 16.9 & 92.3 & $\mathrm{n} / \mathrm{a}$ & $\mathrm{n} / \mathrm{a}$ & $\mathrm{n} / \mathrm{a}$ \\
\hline & a. 5 & 0.2 & 2.8 & 15.9 & 87.8 & $\mathrm{n} / \mathrm{a}$ & $\mathrm{n} / \mathrm{a}$ & $\mathrm{n} / \mathrm{a}$ \\
\hline & a. 6 & 2.1 & 97.0 & 16.3 & 83.5 & $\mathrm{n} / \mathrm{a}$ & $\mathrm{n} / \mathrm{a}$ & $\mathrm{n} / \mathrm{a}$ \\
\hline & a. 7 & 1.8 & 96.3 & 16.3 & 84.3 & $\mathrm{n} / \mathrm{a}$ & $\mathrm{n} / \mathrm{a}$ & $\mathrm{n} / \mathrm{a}$ \\
\hline & a. 8 & 8.7 & 131.5 & 16.0 & 82.7 & $\mathrm{n} / \mathrm{a}$ & $\mathrm{n} / \mathrm{a}$ & $\mathrm{n} / \mathrm{a}$ \\
\hline & a.9 & 1.9 & 101.0 & 15.4 & 88.4 & $\mathrm{n} / \mathrm{a}$ & $\mathrm{n} / \mathrm{a}$ & $\mathrm{n} / \mathrm{a}$ \\
\hline & a. 10 & 0.4 & 3.7 & 16.1 & 91.0 & $\mathrm{n} / \mathrm{a}$ & $\mathrm{n} / \mathrm{a}$ & $\mathrm{n} / \mathrm{a}$ \\
\hline & Mean & 4.8 & 70.6 & 16.1 & 88.8 & & & \\
\hline & CV\% & 157.9 & 67.4 & 2.7 & 5.2 & & & \\
\hline \multirow{13}{*}{$\begin{array}{l}\text { Silage Cut } \\
\text { (SC) }\end{array}$} & Original $b$ & 9.0 & 77.7 & 16.6 & 89.2 & 12.6 & 14.8 & 5.49 \\
\hline & b. 1 & 10.3 & 102.8 & 15.9 & 91.0 & 9.2 & 21.6 & 5.38 \\
\hline & b. 2 & 43.3 & 114.9 & 15.4 & 87.2 & 16.3 & 25.4 & 5.35 \\
\hline & b. 3 & 10.5 & 96.5 & 15.9 & 93.5 & 18.4 & 51.5 & 5.30 \\
\hline & b. 4 & 4.8 & 92.8 & 15.9 & 91.4 & 14.0 & 20.4 & 5.44 \\
\hline & b. 5 & 8.2 & 115.9 & 15.9 & 94.1 & 14.3 & 35.9 & 5.38 \\
\hline & b. 6 & 2.2 & 83.5 & 16.1 & 91.6 & 13.1 & 39.4 & 5.29 \\
\hline & b. 7 & 9.6 & 93.1 & 16.0 & 95.1 & 13.0 & 23.2 & $\mathrm{n} / \mathrm{a}$ \\
\hline & b. 8 & 1.8 & 563.1 & 16.1 & 89.0 & 16.3 & 25.4 & 5.67 \\
\hline & b. 9 & 0.3 & 1.63 & 16.3 & 91.2 & 18.4 & 51.5 & 5.67 \\
\hline & b. 10 & 2.2 & 120.8 & 16.4 & 89.4 & 14.0 & 20.4 & 5.58 \\
\hline & Mean & 9.3 & 133.0 & 16.0 & 91.1 & 14.5 & 30.0 & 5.46 \\
\hline & CV\% & 128.1 & 110.0 & 2.0 & 2.6 & 18.8 & 42.5 & 2.6 \\
\hline
\end{tabular}

n/a samples not analysed. 
Table 4. Measured and mean values from the sets of 10 gas sampling chambers ( $a$ and $b$ ) surrounding a chamber with high flux (original $a+$ original $b$ ) from the Young Stock grazed field $(\mathrm{YG})$

\begin{tabular}{|c|c|c|c|c|c|c|c|c|}
\hline Field & Chambers & $\begin{array}{l}\mathrm{N}_{2} \mathrm{O} \text { flux } \\
\mathrm{ng} \mathrm{N} \\
\mathrm{m}^{-2} \mathrm{~s}^{-1}\end{array}$ & $\begin{array}{l}\mathrm{CO}_{2} \text { flux } \\
\mathrm{ng} \mathrm{C} \\
\mathrm{m}^{-2} \mathrm{~s}^{-1}\end{array}$ & Temp ${ }^{\circ} \mathrm{C}$ & $\begin{array}{l}\text { WFPS } \\
\%\end{array}$ & $\mathrm{NH}_{4}: \mathrm{N}$ (soil DM) $\mu \mathrm{g} \mathrm{g}^{-1}$ & $\mathrm{NO}_{3}: \mathrm{N}$ (soil DM) $\mu \mathrm{g} \mathrm{g}^{-1}$ & $\begin{array}{l}\mathrm{pH} \\
\mathrm{H}_{2} \mathrm{O}\end{array}$ \\
\hline Young Stock & Original a & 80.7 & 187.7 & 18.9 & 84.4 & $\mathrm{n} / \mathrm{a}$ & $\mathrm{n} / \mathrm{a}$ & $\mathrm{n} / \mathrm{a}$ \\
\hline \multirow[t]{12}{*}{ Grazed (YG) } & a.1 & 77.5 & 208.1 & 18.7 & 85.9 & $\mathrm{n} / \mathrm{a}$ & $\mathrm{n} / \mathrm{a}$ & $\mathrm{n} / \mathrm{a}$ \\
\hline & a. 2 & 96.9 & 204.4 & 18.7 & 83.0 & $\mathrm{n} / \mathrm{a}$ & $\mathrm{n} / \mathrm{a}$ & $\mathrm{n} / \mathrm{a}$ \\
\hline & a. 3 & 110.4 & 160.6 & 18.7 & 85.3 & $\mathrm{n} / \mathrm{a}$ & $\mathrm{n} / \mathrm{a}$ & $\mathrm{n} / \mathrm{a}$ \\
\hline & a. 4 & 453.1 & 224.0 & 18.4 & 89.1 & 32.2 & 81.7 & 5.19 \\
\hline & a. 5 & 218.5 & 285.1 & 18.8 & 94.9 & 20.3 & 44.9 & 5.45 \\
\hline & a. 6 & 19.8 & 201.7 & 18.9 & 93.5 & 26.3 & 26.0 & 5.45 \\
\hline & a.7 & 314.6 & 196.5 & 19.3 & 85.7 & 22.1 & 49.9 & 5.44 \\
\hline & a. 8 & 80.8 & 213.3 & 18.8 & 92.7 & 18.2 & 33.3 & 5.52 \\
\hline & a.9 & 8.8 & 39.5 & 18.8 & 89.3 & 20.0 & 14.2 & 5.34 \\
\hline & a. 10 & 99.1 & 106.0 & 19.0 & 90.7 & 27.4 & 32.3 & 5.38 \\
\hline & Mean & 141.8 & 184.3 & 18.8 & 88.6 & 23.8 & 40.3 & 5.39 \\
\hline & $\mathrm{CV} \%$ & 95.0 & 35.0 & 1.2 & 4.5 & 21.1 & 53.8 & 2.0 \\
\hline Young Stock & Original $b$ & 3.2 & 33.4 & 18.4 & 93.3 & 22.8 & 27.5 & 5.38 \\
\hline \multirow{12}{*}{ Grazed (YG) } & b. 1 & 106.6 & 235.2 & 18.4 & 88.7 & 18.4 & 86.3 & 5.10 \\
\hline & b. 2 & 14.4 & 83.5 & 18.4 & 89.5 & 12.3 & 20.0 & 5.53 \\
\hline & b. 3 & 47.8 & 202.2 & 18.4 & 94.5 & 19.2 & 41.9 & 5.33 \\
\hline & b. 4 & 72.7 & 264.8 & 17.2 & 89.1 & 25.5 & 55.8 & 5.04 \\
\hline & b. 5 & 41.4 & 145.5 & 18.5 & 88.1 & 27.4 & 32.3 & 5.45 \\
\hline & b. 6 & 57.4 & 179.6 & 18.4 & 87.3 & 18.5 & $\mathrm{n} / \mathrm{a}$ & 5.26 \\
\hline & b. 7 & 69.2 & 221.8 & 18.5 & 82.0 & 23.0 & $\mathrm{n} / \mathrm{a}$ & 5.54 \\
\hline & b. 8 & 29.4 & 203.8 & 18.4 & 82.4 & 15.8 & $\mathrm{n} / \mathrm{a}$ & 5.29 \\
\hline & b.9 & 569.7 & 206.0 & 18.0 & 83.4 & 17.7 & $\mathrm{n} / \mathrm{a}$ & 5.47 \\
\hline & b. 10 & 23.4 & 110.0 & 18.0 & 96.7 & 15.6 & $\mathrm{n} / \mathrm{a}$ & 5.47 \\
\hline & Mean & 94.1 & 171.4 & 18.2 & 88.6 & 19.6 & 44.0 & 5.35 \\
\hline & CV\% & 170.5 & 41.2 & 2.1 & 5.5 & 23.2 & 54.9 & 3.1 \\
\hline
\end{tabular}

$\mathrm{n} / \mathrm{a}$ samples not analysed.
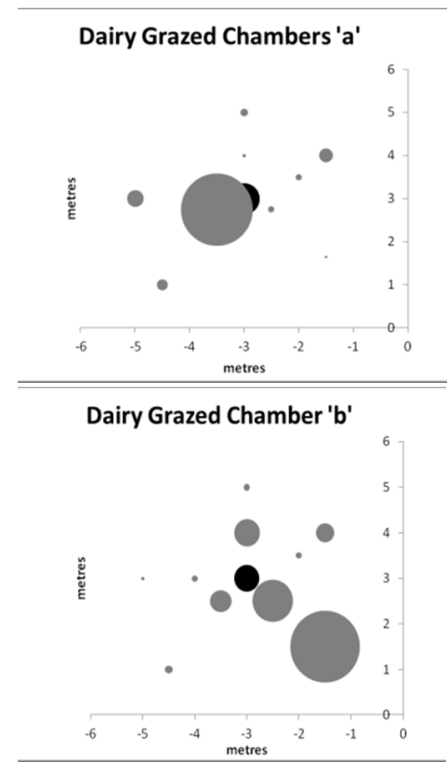
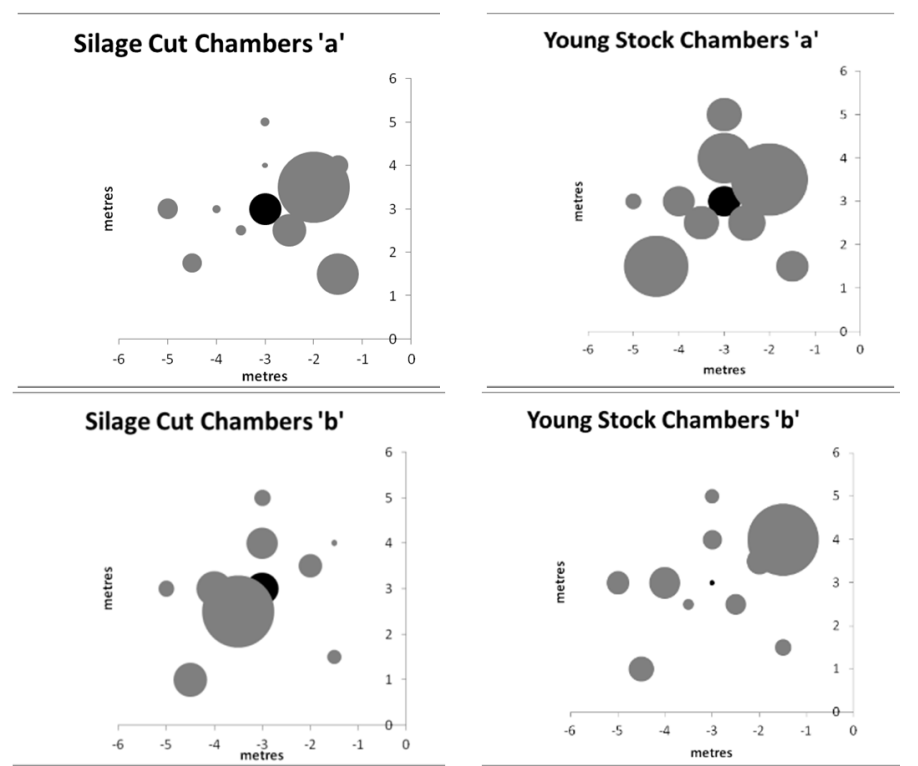

Figure 2. Magnitude of the $\mathrm{N}_{2} \mathrm{O}$ flux from the chambers located around the historic 'hot-spot' chamber in each of the three fields; Dairy-cattle grazed (DG) - flux ranges 4.3 to $2885 \mathrm{ng} \mathrm{N} \mathrm{m}^{-2} \mathrm{~s}^{-1}$, Silage Cut (SC) - flux ranges 0.2 to $128 \mathrm{ng} \mathrm{N} \mathrm{m}^{-2} \mathrm{~s}^{-1}$ and grazed by Young Stock (YS) - flux ranges 3.2 to $570 \mathrm{ng} \mathrm{N} \mathrm{m}^{-2} \mathrm{~s}^{-1}$. The larger the area of the circle the greater the $\mathrm{N}_{2} \mathrm{O}$ flux 
The correlations between the $\log \mathrm{N}_{2} \mathrm{O}$ fluxes and the $\mathrm{CO}_{2}$ fluxes (Figure 3) were significant for all chambers in both grazed fields (DG, $P<0.001$ and YG, $P<0.05$ ) and for the 'a' set of chambers in the silage cut field (SC, $P<0.01)$. Correlation in the ' $\mathrm{b}$ ' set of chambers in $\mathrm{SC}$ was poor ( $\mathrm{R} 0.1)$, but improved, when a very high $\mathrm{CO}_{2}$ flux was removed (R 0.74, $P<0.01$ ) (Figure $3 \mathrm{e}$ ).

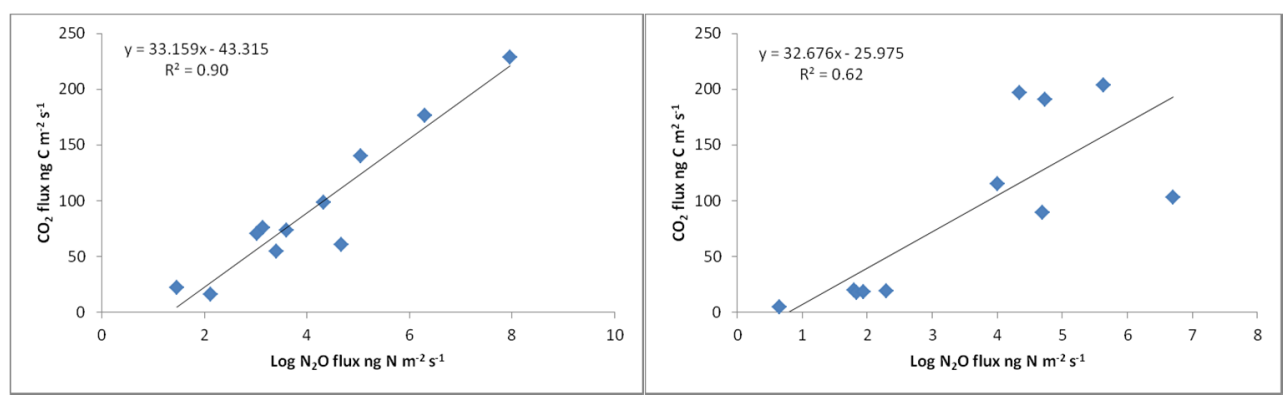

A) Dairy Grazed (DG) chambers 'a'

B) Dairy Grazed (DG) chambers ' $b$ '

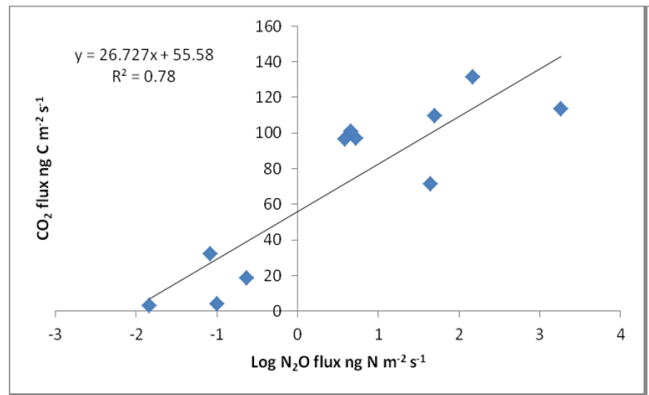

C) Silage Cut (SC) chambers 'a'

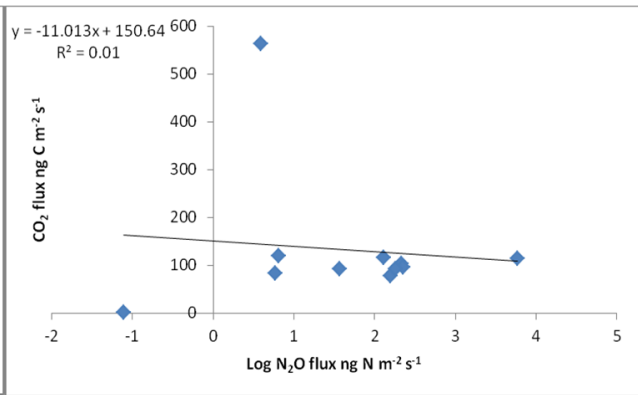

D) Silage Cut (SC) chambers ' $b$ '

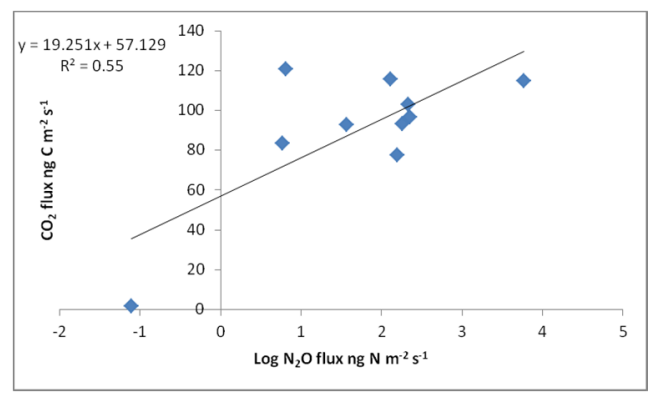

E) Silage $\mathrm{Cut}(\mathrm{SC})$ chambers 'b' with high $\mathrm{CO}_{2}$ point removed

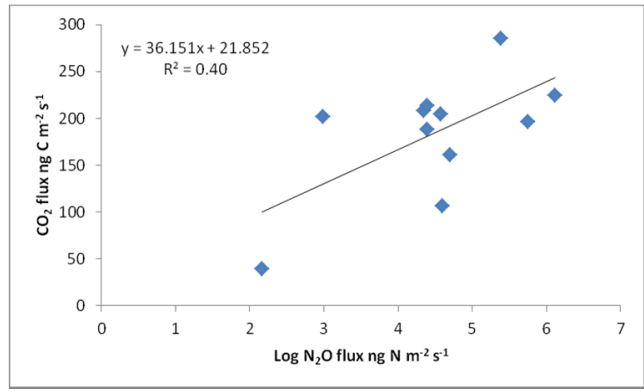

F) Young Stock (YG) chambers ' $a$ '

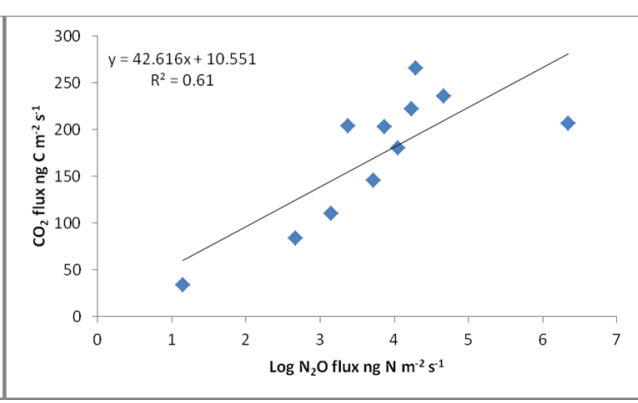

G) Young Stock (YG) chambers ' $b$ '

Figure 3. $\log \mathrm{N}_{2} \mathrm{O}$ flux and $\mathrm{CO}_{2}$ for sets of hot-spot chambers ' $a$ ' and ' $b$ ' in each of the three fields; $\mathrm{A}$ ) and $\mathrm{B}$ ) Dairy Grazed (DG), C) and D) Silage Cut (SC) and E) Silage Cut chambers 'b' with high $\mathrm{CO}_{2}$ point removed and F) and G) Young stock Grazed (YG) 
The coefficient of variation ( $\mathrm{CV} \%$ ) of $\mathrm{N}_{2} \mathrm{O}$ flux measurements from the pooled data within each field was greatest for the two sets of chambers in DG $(241.6 \%$ and $179.0 \%)$ and least for the set of chambers ' $a$ ', in YG (95.0\%). The $\mathrm{CV}$ of $\mathrm{N}_{2} \mathrm{O}$ flux among the other set of chambers in $\mathrm{YG}(170.5 \%)$ was closer in magnitude to that in the other grazed field, DG. Although the fluxes in SC were much lower, the CV's for the sets of sampling chambers in SC were also close to those in the grazed fields (157.9 and 128.1\%).

In most sets of chambers in the three fields the greatest $\mathrm{N}_{2} \mathrm{O}$ flux (Figure 2) was not the original hot spot. The number of chambers giving higher $\mathrm{N}_{2} \mathrm{O}$ fluxes than the original hot-spot chamber varied from one (DG ' $\mathrm{a}$ ') to four in YG ' $b$ '. Chambers DG ' $a$ ', SC ' $a$ ', SC ' $b$ ' and $Y G$ ' $a$ ' had higher fluxes at $1 \mathrm{~m}$ radius from the original chamber, in contrast with chambers $D G$ ' $b$ ', and $Y G$ ' $b$ ' where $\mathrm{N}_{2} \mathrm{O}$ fluxes were greater in one or more chambers at $2 \mathrm{~m}$ radius from the original chamber. $\mathrm{N}_{2} \mathrm{O}$ fluxes from the chambers around $\mathrm{YG}$ ' $\mathrm{a}$ ' also indicated a possible second hotspot of $\mathrm{N}_{2} \mathrm{O}$ for chamber 'a.7', opposite the cluster of chambers around the original hotspot.

CVs for $\mathrm{CO}_{2}$ fluxes for YG (35.0 and 41.2\%) were significantly smaller than DG (70.4 and 89.3\%) and SC, (67.4 and $110.0 \%$ ), but still indicated a high heterogeneity in relation to microbial activity.

The greatest mean $\mathrm{CO}_{2}$ fluxes were from the YG chambers $\left(177.9 \mathrm{ng} \mathrm{C} \mathrm{m}^{-2} \mathrm{~s}^{-1}\right)$ and were approximately double those in the DG chambers and 1.7 times greater than the mean for the SC chambers.

The mean soil temperature measurement was significantly lower at SC $(P<0.001)$, the only other variable measured that showed a comparable pattern to the $\mathrm{N}_{2} \mathrm{O}$ fluxes, across the three fields. The only other significant correlation for the $\log$ of $\mathrm{N}_{2} \mathrm{O}$ was with $\mathrm{NO}_{3}{ }^{-}(\mathrm{R} 0.87, P<0.05)$ for the $\mathrm{YG}$ (chambers 'a').

\subsection{Old Urine and Dung Patches and Effects on $\mathrm{N}_{2} \mathrm{O}$ Fluxes}

Table 5. Measured and mean values from gas sampling chambers and related soils placed over normally grazed, old ungrazed urine patches (no indication of dung) and old dung patches (YG field)

\begin{tabular}{|c|c|c|c|c|c|c|c|c|}
\hline Field & Chambers & $\begin{array}{l}\mathrm{N}_{2} \mathrm{O} \text { flux } \\
\mathrm{ng} \mathrm{N} \\
\mathrm{m}^{-2} \mathrm{~s}^{-1}\end{array}$ & $\begin{array}{l}\mathrm{CO}_{2} \text { flux } \\
\mathrm{ng} \mathrm{C} \\
\mathrm{m}^{-2} \mathrm{~s}^{-1}\end{array}$ & Temp ${ }^{\circ} \mathrm{C}$ & $\begin{array}{l}\text { WFPS } \\
\%\end{array}$ & $\begin{array}{l}\mathrm{NH}_{4}: \mathrm{N} \\
\text { (soil DM) } \mu \mathrm{g} \mathrm{g}^{-1}\end{array}$ & $\begin{array}{l}\mathrm{NO}_{3}: \mathrm{N} \\
\text { (soil DM) } \mu \mathrm{g} \mathrm{g}^{-1}\end{array}$ & $\begin{array}{l}\mathrm{pH} \\
\mathrm{H}_{2} \mathrm{O}\end{array}$ \\
\hline Young Stock & 7 Normal & 21.8 & 104.5 & 18.7 & 89.7 & 14.2 & 5.6 & 5.59 \\
\hline \multirow[t]{14}{*}{ (YS) } & 10 Normal & 14.9 & 56.9 & 18.3 & 88.9 & 11.0 & 7.8 & 5.57 \\
\hline & 13 Normal & 15.7 & 109.4 & 18.6 & 92.7 & 14.1 & 4.8 & 5.62 \\
\hline & 16 Normal & 8.0 & 19.8 & 18.7 & 87.9 & 11.0 & 7.8 & 5.40 \\
\hline & Mean & 15.1 & 72.6 & 18.6 & 89.8 & 12.6 & 6.5 & 5.54 \\
\hline & 8 Urine & 280.3 & 57.0 & 18.0 & 91.1 & 20.4 & 5.6 & 5.61 \\
\hline & 11 Urine & 70.3 & 52.3 & 17.3 & 79.0 & 16.7 & 7.5 & 5.52 \\
\hline & 14 Urine & 33.2 & 189.8 & 17.9 & 88.3 & 20.4 & 5.6 & 5.52 \\
\hline & 17 Urine & 265.1 & 301.4 & 17.8 & 73.2 & 16.7 & 7.5 & 5.42 \\
\hline & Mean & 162.2 & 150.1 & 17.8 & 82.9 & 18.5 & 6.5 & 5.52 \\
\hline & 9 Dung & 15.0 & 27.9 & 17.5 & 89.9 & 19.3 & 11.7 & 5.43 \\
\hline & 12 Dung & 8.4 & 28.0 & 18.0 & 83.6 & 13.8 & 5.6 & 5.46 \\
\hline & 15 Dung & 0.3 & 143.8 & 17.5 & 95.7 & 19.3 & 11.7 & 5.58 \\
\hline & 18 Dung & 0.9 & 184.5 & 17.8 & 92.3 & 13.8 & 5.6 & 5.80 \\
\hline & Mean & 6.2 & 96.1 & 17.7 & 90.4 & 16.5 & 8.6 & 5.57 \\
\hline
\end{tabular}

On average the highest mean $\mathrm{N}_{2} \mathrm{O}$ flux for this part of the study (Table 5) was from the gas sampling chambers placed over the old urine patches, $162.2 \mathrm{ng} \mathrm{N} \mathrm{m}^{-2} \mathrm{~s}^{-1}$, and was significantly greater $(P<0.05)$, than 15.1 and 6.2 ng $\mathrm{N} \mathrm{m}^{-2} \mathrm{~s}^{-1}$ for the normally grazed areas and dung patches, respectively. The mean $\mathrm{CO}_{2}$ fluxes followed a 
similar pattern to the mean $\mathrm{N}_{2} \mathrm{O}$ fluxes, with the greatest mean values in the former urine patches, $150.1 \mathrm{ng} \mathrm{C} \mathrm{m}^{-2}$ $\mathrm{s}^{-1}$. The $\mathrm{N}_{2} \mathrm{O}$ fluxes from the normally grazed areas were most closely correlated, in general, with the other measured variables but were only significant $(\mathrm{R} 0.88, P<0.05)$ between $\log \mathrm{N}_{2} \mathrm{O}$ flux and $\mathrm{CO}_{2}$ flux. Nevertheless, the mean WFPS was lowest for the old urine patches $(82.9 \%)$ compared to the normally grazed areas $(89.8 \%)$ or dung chambers $(90.4 \%)$.

As expected the mean soil $\mathrm{NH}_{4}{ }^{+}\left(18.5 \mu \mathrm{g} \mathrm{N} \mathrm{g}^{-1}\right)$ concentration in the old urine patches was the highest, with the mean of the old dung areas being slightly lower $\left(16.5 \mu \mathrm{g} \mathrm{N} \mathrm{g}{ }^{-1}\right)$ compared to the normally grazed areas (12.6 $\mu \mathrm{g}$ $\left.\mathrm{N} \mathrm{g}^{-1}\right)$. The greatest mean $\mathrm{NO}_{3}{ }^{-}$content was under the old dung chambers $\left(8.6 \mu \mathrm{g} \mathrm{N} \mathrm{g}^{-1}\right)$ with the old urine and normal grazed chambers giving the same mean concentration of $6.5 \mu \mathrm{g} \mathrm{N} \mathrm{g}^{-1}$.

The range of mean soil $\mathrm{pH}$ for the three sets of chambers was narrow, between 5.50 and 5.60. Unsurprisingly, considering the potential $\mathrm{N}$ addition from urine and dung, statistically significant correlations between $\mathrm{NH}_{4}{ }^{+}$and $\mathrm{NO}_{3}{ }^{-}$were found in the normally grazed grass, old urine and dung patches ( $\mathrm{R} 0.97, \mathrm{R} 0.98$ and $\mathrm{R} 0.98 P<0.05$ ), respectively.

\subsection{Effect of Fresh Dung and Synthetic Urine Application on $\mathrm{N}_{2} \mathrm{O}$ Fluxes}

The addition of fresh dung to the gas sampling chambers gave mean $\mathrm{N}_{2} \mathrm{O}\left(1574.2 \mathrm{ng} \mathrm{N} \mathrm{m}^{-2} \mathrm{~s}^{-1}\right)$ and $\mathrm{CO}_{2}$ fluxes $\left(208.3 \mathrm{ng} \mathrm{C} \mathrm{m}^{-2} \mathrm{~s}^{-1}\right)$ that were significantly greater $(P<0.01)$ than those from the urine addition chambers $(53.7$ ng N m${ }^{-2} \mathrm{~s}^{-1}, 13.3 \mathrm{ng} \mathrm{C} \mathrm{m}^{-2} \mathrm{~s}^{-1}$ ) (Table 6).

Table 6. Measured and mean values from gas sampling chambers and related soils variables on control, fresh synthetic urine addition or fresh dung addition to gas chambers (DG) field

\begin{tabular}{|c|c|c|c|c|c|c|c|c|}
\hline Field & Chambers & $\begin{array}{l}\mathrm{N}_{2} \mathrm{O} \text { flux } \\
\mathrm{ng} \mathrm{N} \\
\mathrm{m}^{-2} \mathrm{~s}^{-1}\end{array}$ & $\begin{array}{l}\mathrm{CO}_{2} \text { flux } \\
\mathrm{ng} \mathrm{C} \\
\mathrm{m}^{-2} \mathrm{~s}^{-1}\end{array}$ & Temp ${ }^{\circ} \mathrm{C}$ & $\begin{array}{c}\text { WFPS } \\
\%\end{array}$ & $\begin{array}{l}\mathrm{NH}_{4}: \mathrm{N} \\
\text { (soil DM) } \mu \mathrm{g} \mathrm{g}^{-1}\end{array}$ & $\begin{array}{l}\mathrm{NO}_{3}: \mathrm{N} \\
\text { (soil DM) } \mu \mathrm{g} \mathrm{g}^{-1}\end{array}$ & $\begin{array}{l}\mathrm{pH} \\
\mathrm{H}_{2} \mathrm{O}\end{array}$ \\
\hline Dairy Grazed & 27 Control & 172.3 & 186.4 & 16.4 & 85.1 & 7.7 & 23.2 & 5.52 \\
\hline \multirow[t]{16}{*}{ (DG) } & 28 Control & 16.5 & 3.6 & 16.9 & 83.0 & 14.8 & $\mathrm{n} / \mathrm{a}$ & 5.23 \\
\hline & 29 Control & 28.2 & 44.0 & 17.7 & 77.7 & 11.9 & 14.9 & 5.57 \\
\hline & 30 Control & 234.4 & 174.4 & 17.1 & 69.5 & 8.8 & 19.0 & 5.54 \\
\hline & 31 Control & 717.8 & 97.1 & 16.9 & 74.4 & 8.9 & 15.2 & 5.56 \\
\hline & 32 Control & 121.5 & 154.6 & 17.3 & 73.5 & 6.3 & 29.2 & 5.41 \\
\hline & 33 Control & 152.8 & 209.6 & 17.5 & 72.3 & 7.7 & 23.2 & 6.03 \\
\hline & 34 Control & 396.4 & 247.9 & 16.8 & 77.3 & 14.8 & $\mathrm{n} / \mathrm{a}$ & 5.56 \\
\hline & Mean & 230.0 & 139.6 & 17.1 & 76.6 & 10.1 & 20.8 & 5.55 \\
\hline & 36 Urine & 16.8 & 7.1 & 17.5 & 77.7 & 14.1 & 17.4 & 5.33 \\
\hline & 38 Urine & 19.8 & 6.2 & 17.4 & 80.0 & 6.9 & 17.0 & 5.37 \\
\hline & 40 Urine & 124.4 & 26.6 & 17.0 & 73.5 & 7.9 & 25.1 & 5.48 \\
\hline & Mean & 53.7 & 13.3 & 17.3 & 77.0 & 9.6 & 19.8 & 5.39 \\
\hline & 35 Dung & 1246.0 & 213.0 & 16.6 & 72.0 & 10.9 & 17.1 & 5.59 \\
\hline & 37 Dung & 151.0 & 147.1 & 17.3 & 80.5 & 49.6 & 22.3 & 5.32 \\
\hline & 39 Dung & 3325.5 & 264.8 & 17.2 & 74.1 & 7.4 & 20.2 & 5.37 \\
\hline & Mean & 1574.2 & 208.3 & 17.0 & 75.5 & 22.6 & 19.8 & 5.43 \\
\hline
\end{tabular}

n/a samples not analysed.

Fluxes of $\log \mathrm{N}_{2} \mathrm{O}$ and $\mathrm{CO}_{2}$ correlated significantly for both the fresh dung $(\mathrm{R} 0.95, P<0.05)$ and urine chambers (R 0.99, $P<0.005$ ). Contrary to expectation, the mean $\mathrm{N}_{2} \mathrm{O}$ and $\mathrm{CO}_{2}$ fluxes for the chambers with no additions 
were greater than the fresh urine. The mean soil $\mathrm{NH}_{4}{ }^{+}$content in the fresh dung chambers $\left(22.6 \mu \mathrm{g} \mathrm{N} \mathrm{g}{ }^{-1}\right)$ was also more than double that for the fresh urine (Table 6).

Overall, the fresh urine chambers showed the largest number of statistically significant relationships between $\log$ $\mathrm{N}_{2} \mathrm{O}$ flux and the soil driving variables, including temperature (R 0.99, $\left.P<0.01\right), \mathrm{NO}_{3}^{-}(\mathrm{R} 0.99, P<0.01)$ and $\mathrm{pH}$ (R 0.97, $P<0.05$ ).

Within the fresh urine application chambers there were further statistically significant relationships between $\mathrm{CO}_{2}$ flux and temperature (R 0.97, $P<0.05)$, soil moisture (R 0.95, $P<0.05)$ and $\mathrm{NO}_{3}{ }^{-}(\mathrm{R} 0.99, P<0.01)$. These relationships were not detected in the fresh dung or the chambers with no additions.

\section{Discussion}

\subsection{Historic Hotspot Chambers}

Higher $\mathrm{N}_{2} \mathrm{O}$ fluxes were consistently observed in the $12.5 \mathrm{~m}^{2}$ area surrounding the original hotspot chambers suggesting that the area of elevated $\mathrm{N}_{2} \mathrm{O}$ or hot-spot was greater than $2 \mathrm{~m}$ in diameter. The area within $1 \mathrm{~m}$ radius $\left(\sim 3 \mathrm{~m}^{2}\right)$ was rather larger than in previous work where a typical urine patch was between $0.2 \mathrm{~m}^{2}$ (Hayes \& Williams, 1993) and $1.1 \mathrm{~m}^{2}$ (Moir, Cameron, Di, Fertsak, 2010), or a dung patch of $\sim 0.2 \mathrm{~m}$ in diameter (Van der Weerden et al., 2011). However the $2 \mathrm{~m}$ radius area 'hot spot' $\left(\sim 12 \mathrm{~m}^{2}\right)$ suggests that the $\mathrm{N}_{2} \mathrm{O}$ fluxes may result from either an amalgamation of contiguous hot spots formed from a number of historic urine and/or dung patches or that they have a topographical element that can produce large flux differences due to changes in soil carbon along with soil moisture and structure (Ball et al., 1997).

Fluxes were all positive though markedly different (Figure 2); the mean $\mathrm{N}_{2} \mathrm{O}$ fluxes for the DG and YG chambers were 34 and 17 times greater than the mean of the SC chambers. Mean $\mathrm{N}_{2} \mathrm{O}$ fluxes for these grazed fields were considerably greater than other grassland systems in Europe (Rees et al., 2013) and the maximum fluxes were comparable to data for another grazed site in the east of Scotland that also received large fertiliser $\mathrm{N}$ inputs (Flechard et al., 2007). Saggar et al. (2004) found that $\mathrm{N}_{2} \mathrm{O}$ emissions for ungrazed pastures were less than $10 \%$ of those from grazed pastures with the difference due to the addition of the excreta from the grazing animals. However, in these fields the reduction in fluxes for the ungrazed fields was much more dramatic with a $97 \%$ reduction compared to DG and $94 \%$ in comparison with YG. This could be due to $\mathrm{N}$ from excreted emissions, though, the overall mineral $\mathrm{N}$ content measurements show that as they were all $>10 \mathrm{mg} \mathrm{g}^{-1}$ dry soil and unlikely to be limiting in both the grazed and ungrazed fields (Conen, Dobbie, Smith., 2000). Nevertheless, there was a significant difference in $\mathrm{N}_{2} \mathrm{O}$ fluxes between the grazed (DG $(P<0.05)$, the $\mathrm{YG}(P<0.001)$ ) and the $\mathrm{SC}$ field. The mean soil temperature was the only driving variable that differed significantly between fields; the mean at $\mathrm{SC}$ was $1.67^{\circ} \mathrm{C}(P<0.001)$ lower than at $\mathrm{DG}$ and $2.45^{\circ} \mathrm{C}(P<0.001)$ lower than YG. The mean $\log \mathrm{N}_{2} \mathrm{O}$ flux data were significantly correlated (R $0.83, P<0.01)$ with mean soil temperature in the three fields. With a good supply of mineral N, temperature would be a significant driver at these WFPS values (Conen et al., 2000). Alves et al. (2012) demonstrated that diurnal $\mathrm{N}_{2} \mathrm{O}$ fluxes were explained largely by the soil temperature changes. Scott et al. (2000), working on similar soils, found that soil surface temperature effected $\mathrm{N}_{2} \mathrm{O}$ emissions. The difference in temperature between the three fields could account for the differences in $\mathrm{N}_{2} \mathrm{O}$ flux as Dobbie \& Smith (2001) showed increased emission rates $\left(\mathrm{Q}_{10}\right)$ of $\mathrm{N}_{2} \mathrm{O}$ fluxes of 2.3 as temperatures increased between 12 and $18^{\circ} \mathrm{C}$ in soil cores after nutrient addition. This has important implications for any soil temperature rises due to weather extremes or progressive warming in the future.

Unlike Schaufler et al. (2010), no significant correlation was found overall between $\mathrm{CO}_{2}$ flux and soil temperature (R 0.2) for all the chambers, however after removal of the very high measurement from the SC set of ' $\mathrm{b}$ ' chambers $\mathrm{R}$ increased to 0.37 and was significant $(P<0.01)$ indicating that the microbial populations producing the $\mathrm{N}_{2} \mathrm{O}$ and the $\mathrm{CO}_{2}$ are both influenced by temperature more than just the general respiration of the microbial population (Mathieu et al., 2006).

However, four out of the six sets of chambers gave significant $(P<0.001) \mathrm{R}$ values over 0.78 for correlations between the $\log$ of $\mathrm{N}_{2} \mathrm{O}$ and $\mathrm{CO}_{2}$ (Figure 3); such correlations probably indicate enhanced soil microbial activity from nutrients, especially $\mathrm{C}$ inputs from the grazing animals' dung and urine, around carbon nuggets $(2-10 \mathrm{~cm}$ diameter) as suggested by Parkin (1987).

Spatial variation of $\mathrm{N}_{2} \mathrm{O}$ emissions can increase as a consequence of anaerobic conditions, related to increased respiration of the soil microbes, following the introduction of a source of decomposable organic matter (Christensen \& Tiedje, 1998), such as an old dung patch which can form C nuggets.

The large CV's of the $\mathrm{N}_{2} \mathrm{O}$ fluxes (95-242\%) within sets of chambers have been observed in other experiments and have been linked to general soil heterogeneity (Yanai et al., 2003; Aarons, O'Conner, Hosseini, \& Gourley, 
2009). Choudhary, Akramkhanov, and Saggar (2002) also found large spatial variation in $\mathrm{N}_{2} \mathrm{O}$ fluxes, with a mean CV of $120 \%$, for a grazed permanent pasture which again reflected the high soil heterogeneity and was attributed to highly localised $(<1 \mathrm{~m})$ concentrations of organic matter, nitrate level or water filled pore space. Mohammad, Roobroeck, Van Cleemput, and Boeckx (2011) also found that soil biological, physical and chemical properties (cores taken $25 \mathrm{~m}$ apart) were highly heterogeneous across a field and related this to inherent soil physical and chemical properties, mainly aggregate diameter, total $\mathrm{C}$, bulk density and the microbial community structure (fungi/bacteria ratio).

\subsection{Old Urine and Dung Patches}

The highest mean $\log \mathrm{N}_{2} \mathrm{O}$ flux (Table 5) was the old urine patches and was accompanied by the highest mean $\mathrm{CO}_{2}$ flux, in contrast the lowest $\mathrm{N}_{2} \mathrm{O}$ flux was for the old dung patches. A lower mean soil temperature under the dung patches (Table 4) compared to the normally grazed chambers was accompanied by greater grass dry matter in the ungrazed old dung patches and this may help explain the reduction in emissions of $\mathrm{N}_{2} \mathrm{O}$. The inverse correlations between $\log \mathrm{N}_{2} \mathrm{O}$ and the $\mathrm{CO}_{2}$ fluxes from the old dung patch chambers ( $\mathrm{R}$ 0.89) may indicate that the carbon source from the dung reduced the microbial $\mathrm{N}_{2} \mathrm{O}$ flux activity as the dung patch aged. As Aarons et al. (2009) found, the addition of dung to soil increased the soil microbial biomass as a result of the increased addition of organic $\mathrm{C}$ and soil $\mathrm{pH}$. This also occurred in the current study where $\mathrm{pH}$ was least acidic in the old dung patches (Table 4).

As Yamulki et al. (1998) found in measurements of $\mathrm{N}_{2} \mathrm{O}$ flux from urine and dung patches, the average flux from urine patches was more than five times greater than from dung, even though the total $\mathrm{N}$ in the dung was greater than urine. The difference in $\mathrm{N}_{2} \mathrm{O}$ flux between the old urine and dung patches could also have been influenced by the greater microbial availability of urea $\mathrm{N}$ from the urine, a form more easily used by the soil microbial groups responsible for $\mathrm{N}_{2} \mathrm{O}$ production (Mathieu et al., 2006).

The lower soil moisture contents for the old urine patches related to the more vigorous grass growth and depletion of available soil moisture in these areas due to avoidance by the grazing animals. Soil moisture for the

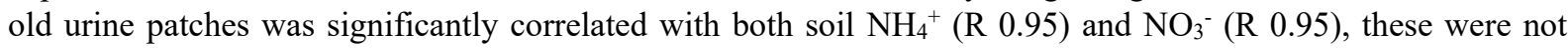
correlated for the old dung patches.

Concentrations of soil $\mathrm{NH}_{4}{ }^{+}$were consistently greater than of $\mathrm{NO}_{3}{ }^{-}$for all the chambers, which was contrasted with the historic hot-spot chambers work reported above, where the $\mathrm{NO}_{3}{ }^{-}$concentrations were mostly greater. An explanation for this could be related to the greater age of the hot-spot patches and that the old dung and urine patches sampled in this experiment were more recent in comparison and there was still soil mineral $\mathrm{NH}_{4}{ }^{+}$to be transformed by microbial activity to mineral $\mathrm{NO}_{3}{ }^{-}$.

\subsection{Effect of Fresh Dung and Synthetic Urine Application to Grassland}

The mean $\mathrm{N}_{2} \mathrm{O}$ fluxes from chambers containing fresh moist dung were considerably greater than those containing fresh urine (Table 6). Allen, Jarvis, Headon (1996) observed a similar higher $\mathrm{N}_{2} \mathrm{O}$ flux from dung application than from urine but over a much longer time period (100 days) and attributed this to the more anaerobic conditions under the dung pat. Our data indicate that potential anaerobic conditions under dung can enhance $\mathrm{N}_{2} \mathrm{O}$ fluxes immediately after application. Overall, in nearly all chambers the concentration of soil mineral $\mathrm{NH}_{4}{ }^{+}$was less than the soil $\mathrm{NO}_{3}{ }^{-}$(Table 5). This is in conflict with the literature that suggests that soil $\mathrm{NH}_{4}{ }^{+}$would normally be greater in the urine application areas, due to more available and labile $\mathrm{NH}_{4}{ }^{+}$than from the dung (Yamulki et al., 1998, van der Weerden et al., 2011, Thomas, Logan, Ironside, \& Bolton, 1988). However, as the measurements in this investigation were taken within hours of the urine and dung application, it is unlikely that the urea from the urine would be detected in that time. With no associated change in the $\mathrm{pH}$ with the application of the urine, as occurred in other studies generally after 1 day (Oenema et al., 1997), it would appear that the urea needs a greater time to move through the soil. The use of synthetic urine could also have suppressed the initial $\mathrm{pH}$ change due to a difference in the hydrolysis of the urea in the presence of hippuric acid in cow urine (Petersen, Stamatiadis, \& Christofides, 2004).

Work by Saarijärvi and Virkajajärvi (2009) showed that the concentration of soluble organic N (SON) increased significantly within days after urine application, compared to a more modest increase and slower release for a dung pat.

Overall, the correlations of the variables measured from the addition of the dung and synthetic urine were more numerous and significant than from the historic hot-spot chamber measurements. This was as expected as there was a large immediate input of both $\mathrm{N}$ and $\mathrm{C}$ from the dung and urine that would effect both the microbial population and the soil chemistry. 


\section{Conclusions}

The spatial heterogeneity of the $\mathrm{N}_{2} \mathrm{O}$ fluxes around the historic hot-spots was considerable and indicated hot-spot areas of up to at least $2 \mathrm{~m}$ in diameter. The smaller diameter patches indicated a contribution from historic urine or dung deposits but the larger diameter hot-spots would be too large to have been created by individual deposits alone and suggests either amalgamation of deposits and/or an influence of the micro-topography of the land surface that enhanced the $\mathrm{N}_{2} \mathrm{O}$ fluxes, this could include the aspect of the slope concentrating both $\mathrm{N}$ and $\mathrm{C}$

The differences in mean emissions between the grazing and silage conservation management was significant and should be an important consideration in the calculation of $\mathrm{N}_{2} \mathrm{O}$ emissions from grassland. The measurement of emissions with greater temporal and spatial replication from grassland with different management histories needs to be an important consideration for future inventory estimates. However, the enhancement of these differences by an increase in temperature between the fields of as little as $1.7^{\circ} \mathrm{C}$ to $2.5^{\circ} \mathrm{C}$ has possible implications for any increase in temperature through weather extremes or climate change by increasing radiative feedback by between $15 \%$ for young stock grazed and $30 \%$ for dairy stock grazed.

Historic hot-spots of dung and urine had more mineral $\mathrm{NO}_{3}{ }^{-}$than $\mathrm{NH}_{4}{ }^{+}$suggesting that potentially more of the $\mathrm{NH}_{4}{ }^{+}$was consumed by the soil microbial community and transformed to $\mathrm{NO}_{3}{ }^{-}$as they potentially have been primed by the addition of the large inputs of $\mathrm{N}$ and $\mathrm{C}$ (in the case of dung) with the microbial population having increased as a result.

The old visible dung patches were sites with higher $\mathrm{CO}_{2}$ emissions and reduced $\mathrm{N}_{2} \mathrm{O}$ emissions compared to the old urine patches, indicating the organic $\mathrm{C}$ from the dung had enhanced the $\mathrm{CO}_{2}$ emissions. The $\mathrm{C}$ had stimulated further activity as a result of the increased organic $\mathrm{C}$ input.

Additions of fresh dung of high moisture content and urine stimulated microbial activity as expected but the dung appeared to have a greater initial effect than the urine, potentially as a consequence of the $\mathrm{NH}_{4}-\mathrm{N}$ in the urine moving more slowly through the soil, coupled with an inhibitory effect of the $\mathrm{NH}_{4}^{+}$and reduced transformation through nitrification to $\mathrm{NO}_{3}{ }^{-}$and a more rapid initial release of $\mathrm{NH}_{4}{ }^{+}$from the dung.

\section{Acknowledgements}

Thank you to Valentini Pappa, John Parker, Colin Crawford and Ainsley Bagnall for help in taking and processing the samples, and to the Scottish Government's Strategic Research Programme for funding.

\section{References}

Aarons, S. R., O’Conner, C. R., Hosseini, H. M., \& Gourley, C. J. P. (2009). Dung pads increase pasture production, soil nutrients and microbial biomass carbon in grazed dairy systems. Nut. Cycl. Agroecosyst., 84, 81-92. http://dx.doi.org/10.1007/s10705-008-9228-5

Adviento-Borbe, M. A. A., Doran, J. W., Drijber, R. A., \& Dobermann, A. (2006). Soil electrical conductivity and water content affect nitrous oxide and carbon dioxide emissions in intensively managed soils. $J$. Environ. Qual., 35, 1999-2010. http://dx.doi.org/10.2134/jeq2006.0109

Allen, A. G., Jarvis, S. C., \& Headon, D. M. (1996). Nitrous oxide emissions from soils due to inputs of nitrogen from excreta return by livestock on grazed grassland in the U.K. Soil Biol. Biochem., 28, 597-607. http://dx.doi.org/10.1016/0038-0717(95)00186-7

Alves, B. J. R., Smith, K. A., Flores, R. A., Cardoso, A. S., Oliveira, W. R. D., Jantalia, C. P. .. Boddey, R. M. (2012). Selection of the most suitable sampling time for static chambers for the estimation of daily mean $\mathrm{N}_{2} \mathrm{O}$ flux from soils. Soil Biol. Biochem., 46, 129-135. http://dx.doi.org/10.1016/j.soilbio.2011.11.022

Ambus, P., Petersen, S.O., \& Soussana, J-F. (2007). Short-term carbon and nitrogen cycling in urine patches assessed by combined carbon-13 and nitrogen-15 labelling. Agric. Ecosyst. Environ., 121, 84-92. http://dx.doi.org/10.1016/j.agee.2006.12.007

Ball, B.C., Horgan, G.W., Clayton, H., \& Parker, J.P. (1997). Spatial variability of nitrous oxide fluxes and controlling soil and topographic properties. J. Environ. Qual., 26, 1399-1409. http://dx.doi.org/10.2134/ jeq1997.00472425002600050029x

Carter, M.S., Klumpp, K., \& Le Roux, X. (2006). Lack of increased availability of root-derived C may explain the low $\mathrm{N}_{2} \mathrm{O}$ emission from low N-urine patches. Nut. Cycl. Agroecosyst., 75, 91-100. http://dx.doi.org/10. 1007/s10705-006-9014-1 
Choudhary, M. A., Akramkhanov, A., \& Saggar, S. (2002). Nitrous oxide emissions from a New Zealand cropped soil: tillage effects, spatial and seasonal variability. Agric. Ecosyst. Environ., 93, 33-43. http://dx.doi.org/10.1016/S0167-8809(02)00005-1

Christensen, S., \& Tiedje, J. M. (1998). Denitrification in the field, analysis of spatial and temporal variability. In D. S. Jenkinson, \& K. A. Smith (Eds.), Nitrogen Efficiency in Agricultural Soils (pp. 295-301). Elsevier, Amsterdam.

Clough, T. J., \& Kelliher, F. M. (2005). Dairy Farm Effluent Effects on Urine Patch Nitrous Oxide and Carbon Dioxide Emissions. J. Environ. Qual., 34, 979-986. http://dx.doi.org/10.2134/jeq2004.0360

Clough, T. J., Ledgard, S. F., Sprosen, M. S., \& Kear, M. J. (1998). Fate of ${ }^{15} \mathrm{~N}$ labelled urine on four soil types. Plant Soil, 199, 195-203. http://dx.doi.org/10.1023/A:1004361009708

Conen, F., Dobbie, K. E., \& Smith, K. A. (2000). Predicting $\mathrm{N}_{2} \mathrm{O}$ emissions from agricultural land through related soil parameters. Global Change Biol., 6, 417-426. http://dx.doi.org/10.1046/j.1365-24 86.2000.00319.x

Crutzen, P. J. (1981). Atmospheric chemical processes of the oxides of nitrogen including nitrous oxide. In: (Ed.) Delwiche, C.C., Denitrification, Nitrification and Atmospheric $\mathrm{N}_{2} \mathrm{O}$. Wiley, Chichester, pp. 17-44.

Dobbie, K. E., \& Smith, K. A. (2001). The effects of temperature, water-filled pore space and land use on N2O emissions from an imperfectly drained gleysol. Eur. J. Soil Sci., 52, 667-673. http://dx.doi.org/10.1046/ j.1365-2389.2001.00395.x

Flechard, C. R., Ambus, P., Skiba, U., Rees, R. M., Hensen, A., van Amstel, A. ... Grosz, B. (2007). Effects of climate and management intensity on nitrous oxide emissions in grassland systems across Europe. Agric. Ecosyst. Environ., 121, 135-152. http://dx.doi.org/10.1016/j.agee.2006.12.024

Fowler, D., Hargreaves, K., Skiba, U., \& Bower, K. (1999). Direct Measurements of the UK Source Strength of Radiatively Active Gases. Final Report, Department of the Environment Transport and the Regions.

Haynes, R. J., \& Williams, P. H. (1993). Nutrient cycling and soil fertility in the grazed pasture ecosystem. Advan. Agron., 49, 119-199. http://dx.doi.org/10.1016/S0065-2113(08)60794-4

Houghton, J. T., \& Ding, Y. (2001). Climate Change 2001. The Scientific Basis - Contribution of Working Group I to the Third Assessment Report of the Intergovernmental Panel on Climate Change (IPCC). Cambridge University Press, Cambridge, UK.

IPCC. (2007). Climate change 2007: The physical life science basis. Group I contribution to the fourth assessment report of the IPCC. Cambridge University Press. Cambridge, UK.

Mathieu, O., Lévêque, J., Hénault, C., Milloux, M-J., Bizouard, F., \& Andreux, F. (2006). Emissions and spatial variability of $\mathrm{N}_{2} \mathrm{O}, \mathrm{N}_{2}$ and nitrous oxide mole fraction at the field scale, revealed with ${ }^{15} \mathrm{~N}$ isotopic techniques. Soil Biol. Biochem., 38, 941-951. http://dx.doi.org/10.1016/j.soilbio.2005.08.010

McGechan, M. B., \& Topp, C. F. E. (2004). Modelling environmental impacts of deposition of excreted nitrogen by grazing dairy cows. Agric. Ecosyst. Environ., 103, 149-164. http://dx.doi.org/10.1016/j.agee. 2003.10.004

Mohammad, M. R. J., Roobroeck, D., Van Cleemput, O., \& Boeckx, P. (2011). Spatial variability and biophysicochemical controls on $\mathrm{N}_{2} \mathrm{O}$ emissions from differently tilled arable soils. Biol. Fert. Soils, 47, 753-766. http://dx.doi.org/10.1007/s00374-011-0580-2

Moir, J. L., Cameron, K. C., Di, H. J., \& Fertsak, U. (2010). The spatial coverage of dairy cattle urine patches in an intensively grazed pasture system. J. Agric. Sci., 149, 473-485. http://dx.doi.org/10.1017/S0021859610 001012

Monaghan, R. M., \& Barraclough, D. (1993). Nitrous oxide and dinitrogen emissions from urine-affected soil under controlled conditions. Plant Soil, 151, 127-138. http://dx.doi.org/10.1007/BF00010793

Oenema, O., Velthof, G. L., Yamulki, S., \& Jarvis, S. C. (1997). Nitrous oxide emissions from grazed grassland. Soil Use Manage., 13, 288-295. http://dx.doi.org/10.1111/j.1475-2743.1997.tb00600.x

Orwin, K. H., Bertram, J. E., Clough, T. J., Condron, L.M., Sherlock, R. R. ... Baird, D. B. (2010). Impact of bovine urine deposition on soil microbial activity, biomass, and community structure. Appl. Soil Ecol., 44, 89-100. http://dx.doi.org/10.1016/j.apsoil.2009.10.004 
Parkin, T. B. (1987). Soil microsites as a source of denitrification variability. Soil Sci. Soc. Am. J., 51, 1194 1199. http://dx.doi.org/10.2136/sssaj1987.03615995005100050019x

Petersen, S. O., Stamatiadis, S., \& Christofides, C. (2004). Short-term nitrous oxide emissions from pasture soil as influenced by urea level and soil nitrate. Plant Soil, 267, 117-127. http://dx.doi.org/10.1007/s11104-005 $-4688-8$

Ravishankara, A. R., Daniel, J. R., \& Portmann, R. W. (2009). Nitrous oxide (N2O): the dominant ozone-depleting substance emitted in the 21 st century. Science, 326, 123-125. http://dx.doi.org/10.1126/ science. 1176985

Reay, D. S., Davidson, E. A., Smith, K. A., Smith, P., Melillo, J. M. ... Crutzen, P. J. (2012). Global agriculture and nitrous oxide emissions. Nature Clim.Change, 2, 410-416. http://dx.doi.org/10.1038/NCLIMATE1458

Rees, R. M., Augustin, J., Alberti, G., Ball, B. C., Boeckx, P., Cantarel, A. .. Wuta, M. (2013). Nitrous oxide emissions from European agriculture - an analysis of variability and drivers of emission from field experiments. Biogeosci. 10, 2671-2682. http://dx.doi.org/10.5194/bg-10-2671-2013

Saarijärvi, K., \& Virkajajärvi, P. (2009). Nitrogen dynamics of cattle dung and urine patches on intensively managed boreal pasture. J. Agric. Sci., 147, 479-491. http://dx.doi.org/10.1017/S0021859609008727

Saggar, S., Andrew, R. M., Tate, K. R., Hedley, C. B., Rodda, N. J., \& Townsend, J. A. (2004). Modelling nitrous oxide emissions from dairy-grazed pastures. Nut. Cycl. Agroecosyst., 68, 243-255. http://dx.doi.org/10.1023/B:FRES.0000019463.92440.a3

Schaufler, G., Kitzler, B., Schindlbacher, A., Skiba, U., Sutton, M. A., \& Zechmeister-Boltenstern, S. (2010). Greenhouse gas emissions from European soils under different land use: effects of soil moisture and temperature. Eur. J. Soil Sci., 61, 683-696. http://dx.doi.org/10.1111/j.1365-2389.2010.01277.x

Scott, A., Crichton, I. J., \& Ball, B. C. (1999). Long-term monitoring of soil gas fluxes with closed chambers using automated and manual systems. J. Environ. Qual., 28, 1637-1643. http://dx.doi.org/10.2134/jeq1999. $00472425002800050030 x$

Scott, A., Ball, B. C., Crichton, I. J., \& Aitken, M. N. (2000). Nitrous oxide and carbon dioxide emissions from grassland amended with sewage sludge. Soil Use Manage., 16, 36-41. http://dx.doi.org/10.1111/j.1475 -2743.2000. tb00170.x

Skiba, U., Jones, S. K., Dragosits, U., Drewer, J., Fowler, D., Rees, R. M. .. Manning, A. J. (2012). UK emissions of the greenhouse gas nitrous oxide. Philosophical Transactions of the Royal Society B-Biological Sciences, 367, 1175-1185. http://dx.doi.org/10.1098/rstb.2011.0356

Smith, P., Martino, D., Cai, Z., Gwary, D., Janzen, H., Kumar, P. ... Sirotenko, O. (2007). Agriculture (Chapter 8). In: Climate change 2007: Mitigation. In: Metz B., Davidson O.R., Bosch P.R., Dave R., \& Meyer L.A. (Eds) Contribution of Working Group III to the Fourth Assessment Report of the Intergovernmental Panel on Climate Change, pp. 497-540. Cambridge University Press, Cambridge, UK and New York, NY, USA.

Sozanska, M., Skiba, U., \& Metcalfe, S. (2002). Developing an inventory of $\mathrm{N}_{2} \mathrm{O}$ emissions from British Soils. Atmos. Environ., 36, 987-998. http://dx.doi.org/10.1016/S1352-2310(01)00441-1

Thomas, R. J., Logan, K. A. B., Ironside, A. D., \& Bolton, G. R. (1988). Transformations and fate of sheep urine-N applied to an upland UK pasture at different times during the growing season. Plant Soil, 107, 173-181. http://dx.doi.org/10.1007/BF02370544

van Groenigen, J. W., Velthof, G. L., van der Bolt, F. J. E., Vos, A., \& Kuikman, P. J. (2005a). Seasonal variation in $\mathrm{N}_{2} \mathrm{O}$ emissions from urine patches: Effects of urine concentration, soil compaction and dung. Plant Soil, 273, 15-27. http://dx.doi.org/10.1007/s11104-004-6261-2

van Groenigen, J. W., Kuikman, P. J., de Groot, W. J. M., \& Velthof, G. L. (2005b). Nitrous oxide emission from urine-treated soil as influenced by urine composition and soil physical conditions. Soil Biol. Biochem., 37, 463-473. http://dx.doi.org/10.1016/j.soilbio.2004.08.009

van der Weerden, T. J., Lu, J., de Klein, C. A. M., Hoogendoorn, C. J., Littlejohn, R. P., \& Rys, G. J. (2011). Disaggregating nitrous oxide emission factors for ruminant urine and dung deposited onto pastoral soils. Agric. Ecosyst. Environ., 141, 426-436. http://dx.doi.org/10.1016/j.agee.2011.04.007

Velthof, G. L., Jarvis, S. C., Stein, A., Allen, A. G., \& Oenema, O. (1996). Spatial variability of nitrous oxide fluxes in mown and grazed grassland on a poorly drained clay soil. Soil Biol. Biochem., 28, 1215-1225. http://dx.doi.org/10.1016/0038-0717(96)00129-0 
Williams, D. L. L., Ineson, P., \& Cowards, P. A. (1999). Temporal variations in nitrous oxide fluxes from urine-affected grassland. Soil Biol. Biochem., 31, 779-788. http://dx.doi.org/10.1016/S0038-0717(98) 00186-2

Wrage, N., Velthof, G. L., van Beusichem, M. L., \& Oenema, O. (2001). Role of nitrifier denitrification in the production of nitrous oxide. Soil Biol. Biochem., 33, 1723-1732. http://dx.doi.org/10.1016/S0038-0717 (01)00096-7

Yamulki, S., Jarvis, S. C., \& Owen, P. (1998). Nitrous oxide emissions from excreta applied in a simulated grazing pattern. Soil Biol. Biochem., 30, 491-500. http://dx.doi.org/10.1016/S0038-0717(97)00145-4

Yanai, J., Sawamoto, T., Oe, T., Kusa, K., Yamakawa, K., Sakamoto, K., Naganawa, T. ... Kosaki, T. (2003). Spatial variability of nitrous oxide emissions and their soil-related determining factors in an agricultural field. J. Environ. Qual., 32, 1965-1977. http://dx.doi.org/10.2134/jeq2003.1965

\section{Copyrights}

Copyright for this article is retained by the author(s), with first publication rights granted to the journal.

This is an open-access article distributed under the terms and conditions of the Creative Commons Attribution license (http://creativecommons.org/licenses/by/3.0/). 